
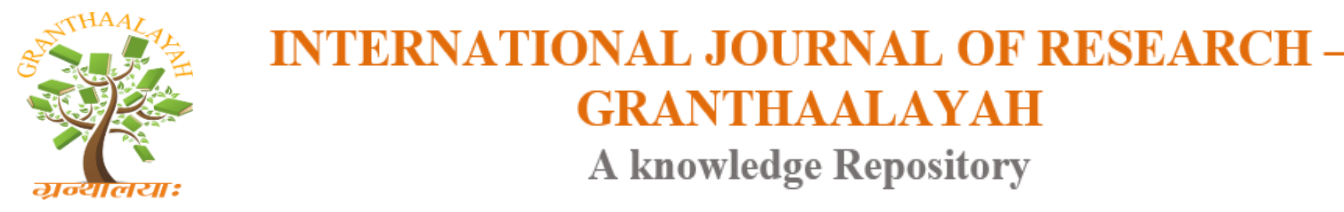

Science

\title{
LEVEL OF IMPLEMENTATION OF THE RESULTS-BASED PERFORMANCE MANAGEMENT SYSTEM IN THE DEPARTMENT OF EDUCATION DIVISION OF GAPAN CITY, PHILIPPINES
}

\author{
Arvin D. Dizon ${ }^{1}$, Anthony B. San Pedro ${ }^{2}$, Marijune M. Munsayac ${ }^{3}$, Josephine Padilla ${ }^{4}$, \\ Maria Cecilia G. Pascual ${ }^{5}$ \\ ${ }^{1}$ DepEd Gapan City \\ ${ }^{2}$ Provincial Cooperative and Entrepreneurship Development Office, LGU Nueva Ecija \\ ${ }^{3,4}$ Provincial Social Welfare and Development Office, LGU Nueva Ecija \\ ${ }^{5}$ Department of Agriculture, LGU Sta Rosa
}

\begin{abstract}
This paper measured the level of implementation of the Results-Based Performance Management (RPMS) as a performance management tool. It focused on the teachers as well as the nonteaching employees of the Department of Education Division of Gapan City, Gapan City, Philippines. The study used the Control Theory of Performance Management System to measure the level of implementation of RPMS. The level of implementation of RPMS was measured in terms of the following phases: a) performance planning and commitment, b) performance monitoring and coaching, c) performance review and evaluation, and d) performance rewards and development planning. The study used as a research tool the survey questionnaire divided into two parts, namely: 1) level of implementation of the RPMS, and 2) challenges in the implementation of the RPMS. The study showed the need for periodic evaluation of the implementation of the RPMS as well as the strict compliance with the RPMS Guidelines.
\end{abstract}

Keywords: Level of Implementation; Performance Management; Results-Based Performance Management System; Human Resource Management; Employee Performance; Department of Education.

Cite This Article: Arvin D. Dizon, Anthony B. San Pedro, Marijune M. Munsayac, Josephine Padilla, and Maria Cecilia G. Pascual. (2018). "LEVEL OF IMPLEMENTATION OF THE RESULTS-BASED PERFORMANCE MANAGEMENT SYSTEM IN THE DEPARTMENT OF EDUCATION DIVISION OF GAPAN CITY, PHILIPPINES." International Journal of Research - Granthaalayah, 6(1), 484-503. 10.29121/granthaalayah.v6.i1.2018.1658.

\section{Introduction}

Performance management is important for an organization. It helps the organizations in ensuring that employees are working hard on achieving the organization's mission and objectives. It also 
sets expectations for employee performance and motivates employees to work hard in ways that are expected of the organization. .

In that manner, the importance of performance management system is realized by improving employee performance which redounds to organizational performance. Thus, improving employee performance by using performance management system is a way to improve corporate performance [1].

In the Department of Education (Dep.Ed), a government agency in the Philippines responsible for ensuring access to, promoting equity in, and improving the quality of basic education[2],the Results-Based Performance Management System (RPMS) is being used a performance management tool for both the teachers and the non-teaching staff.

The RPMS is an organization-wide process of ensuring that employees focus work efforts towards achieving the DepEd vision, mission, values, and strategic priorities. It is also a mechanism to manage, monitor and measure performance, and identify human resource and organizational development needs [3].

The said performance management system is aligned with the Strategic Performance Management System (SPMS) of the Civil Service Commission (CSC), a government agency in the Philippines with responsibility for the civil service[4].The CSC Memorandum Circular (MC) No. 06, series of 2012, sets the guidelines for the implementation of the SPMS in all government agencies. The SPMS emphasizes the strategic alignment of the agency's thrusts with the day-today operation of the units and individual personnel within the organization. It focuses on measures of performance vis-á-vis realized target, employee output and collective performance of the group. [5].

With the the RPMS as its SPMS, DepEd strengthens the culture of performance and accountability in the agency while upholding its organizational mandate, vision, and mission. The Department believes that there is a need to link corporate goal and performance measurement. The system of measurement is important to track individual performance and its contribution to overall goals. Moreover, by cascading the accountabilities to the entire agency, units, department, and own employees, creates a factual basis for performance target. The SPMS is linked with the RPMS to ensure adherence to the principle of performance-based tenure and incentives [3].

Given the above concern, performance management should be an important step in the organization's human resource management system as it can influence employee performance and organizational performance. Thus, performance management and appraisal system are indispensable in achieving productivity. [6].

Therefore, it is essential that this research was conducted to understand the DepEd employees' experiences and perceptions of the Results-Based Performance Management System. Findings show that the proper authorities can build up a completed and comprehensive performance management system. Moreover, it is important for employees and performance raters to 
understand that performance management and performance management systems can be key determinants of an organization's long-term success or failure [7].

\subsection{Objectives of the Study}

This study aimed to measure the level of implementation of the Results-Based Performance Management System inthe Department of Education Division of Gapan City.

Specifically, this study aimed to:

1) Describe the extent of the implementation of the Results-Based Performance Management System in the following phases:

- Performance Planning and Commitment;

- Performance Monitoring and Coaching;

- Performance Review and Evaluation; and

- Performance Rewards and Development Planning;

2) Describe the challenges in the implementation of the Results-Based Performance Management System; and

3) Propose policy recommendations on the implementation of the Results-based Performance Management System.

\section{Research Methodology}

\subsection{Study Locale}

The study locale is the Division of Gapan City, one of the school's divisions of the Department of Education Region III, Philippines [8].It is composed of 41 public schools, 33 of which are elementary schools and the 8 are secondary schools. As of July 2017, it is composed of 41,386 students [9] and 1,086 employees [10].

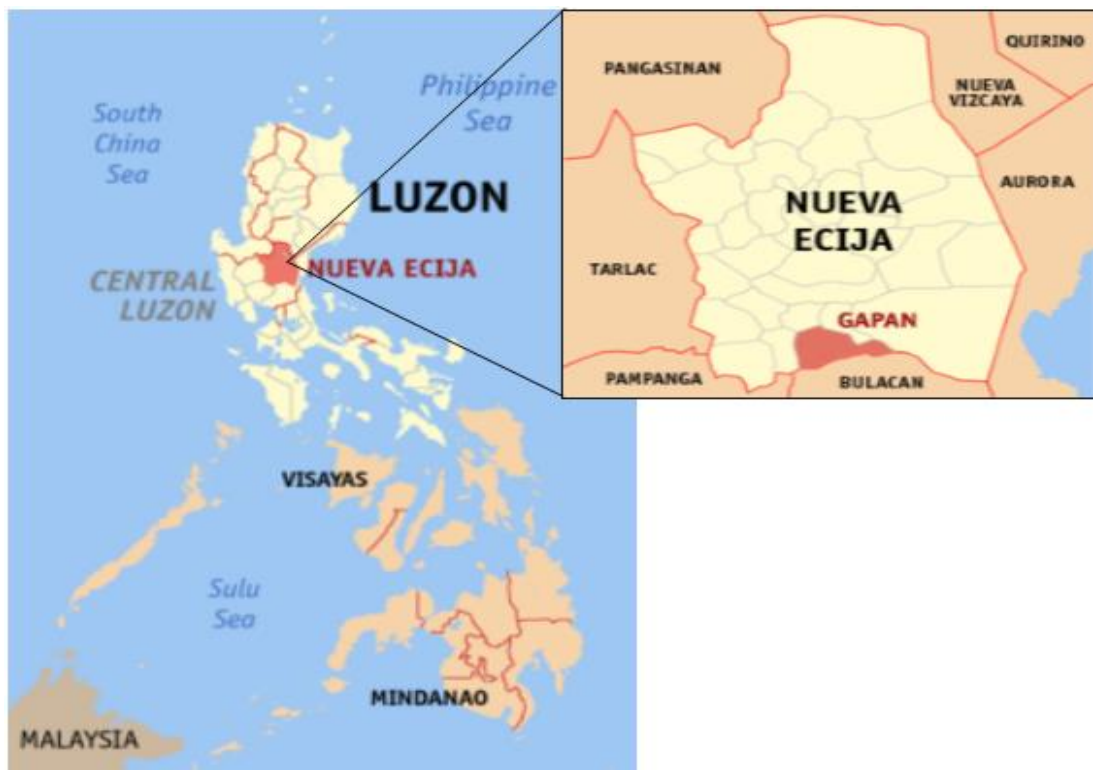

Figure 1: Location of Gapan City. Source: Google Maps, 2017 


\subsection{Study Design}

The study is a mixture of qualitative and quantitative in design. The quantitative tools consist of the self-made survey and qualitative part involved, description, observation, interview and analysis of the data observed.

The survey questionnaire is composed of two (2) parts. The first part analyzed the level of implementation of the RPMS in four different phases: a) performance planning and commitment, b) performance monitoring and coaching, c) performance review and evaluation, and d) performance rewards and development planning. Each phase is composed of 10 items. The following scoring guide was used to determine the level of implementation of the RPMS:

\begin{tabular}{|l|l|}
\hline Weighted Mean & Verbal Interpretation \\
\hline $4.20-5.00$ & To a Very Great Extent \\
\hline $3.40-4.19$ & To a Great Extent \\
\hline $2.60-3.39$ & To a Little Extent \\
\hline $1.80-2.59$ & To a Very Little Extent \\
\hline $1.00-1.79$ & No Extent At All \\
\hline
\end{tabular}

The second part of the survey questionnaire described the challenges in the implementation of the RPMS. It is composed of twenty (20) items. The following scoring guide was used to analyze the challenges in the implementation of the RPMS:

\begin{tabular}{|l|l|}
\hline Weighted Mean & Verbal Interpretation \\
\hline $4.20-5.00$ & Highly Evident \\
\hline $3.40-4.19$ & Evident \\
\hline $2.60-3.39$ & Moderately Evident \\
\hline $1.80-2.59$ & Slightly Evident \\
\hline $1.00-1.79$ & Not Evident \\
\hline
\end{tabular}

\subsection{Respondents}

The respondents of this study were the teachers and non-teaching employees of the Department of Education Division of Gapan City. All the schools, as well as the Division Office, were included in selecting the respondents. 220 employees or $20 \%$ of the population of the Division of Gapan City were selected through random sampling as respondents of the study.

\begin{tabular}{|l|l|l|l|}
\hline School & $\begin{array}{l}\text { Number of } \\
\text { Respondents }\end{array}$ & School & $\begin{array}{l}\text { Number of } \\
\text { Respondents }\end{array}$ \\
\hline Bagong Silang ES & 2 & Gapan South CS & 12 \\
\hline Balante ES & 2 & Malimba ES & 3 \\
\hline Bungo ES & 2 & Marelo ES & 2 \\
\hline Cardenas ES & 2 & Parcutela ES & 2 \\
\hline Gapan East CS & 6 & Punot ES & 2 \\
\hline Gapan North CS & 9 & San Nicolas CS & 8 \\
\hline Kapalangan ES & 3 & San Nicolas West ES & 2 \\
\hline
\end{tabular}




\begin{tabular}{|l|l|l|l|}
\hline $\begin{array}{l}\text { Kapalangan Munti } \\
\text { ES }\end{array}$ & 1 & San Roque ES & 7 \\
\hline $\begin{array}{l}\text { Lupang Pangarap } \\
\text { ES }\end{array}$ & 2 & Sto. Cristo Norte ES & 3 \\
\hline Mabuga ES & 2 & Sto. Cristo Proper ES & 1 \\
\hline Maburak ES & 3 & Sto. Cristo Sur ES & 3 \\
\hline Mahipon ES & 2 & Sto. Niño ES & 2 \\
\hline Mangino ES & 6 & $\begin{array}{l}\text { Herminio G. Nicolas } \\
\text { HS }\end{array}$ & 5 \\
\hline Pambuan ES & 6 & $\begin{array}{l}\text { Juan R. Liwag Mem'l } \\
\text { HS }\end{array}$ & 49 \\
\hline Puting Tubig ES & 2 & Kapalangan NHS & 2 \\
\hline $\begin{array}{l}\text { Sapang Kawayan } \\
\text { ES }\end{array}$ & 2 & Maruhat NHS & 4 \\
\hline St. Joseph ES & 2 & Pambuan NHS & 6 \\
\hline Sta. Cruz ES & 4 & San Nicolas NHS & 7 \\
\hline Velcar ES & 2 & San Roque NHS & 14 \\
\hline $\begin{array}{l}\text { Amando Maniquiz } \\
\text { ES }\end{array}$ & 2 & Sta. Cruz NHS & 12 \\
\hline Bayanihan ES & 2 & Division Office & 10 \\
\hline Total & & & $\mathbf{2 2 0}$ \\
\hline
\end{tabular}

\subsection{Theoretical Framework}

This study is guided by the Control Theory of Performance Management System. The theory helps in sustaining the performance management system by defining forms of control between the organization and the systems within. According to the control theory, actions of all systems should be in sync with the overall goals and objectives of an organization [11].

Control Theory focuses on control mechanisms imposed at all levels of an organization. They may be behavioral or organizational, and the goals should be aligned with organizational goals and objectives. [11].

The Control Theoryhas three types of control systems: 1) behavior control, rewarding job well donse and penalizing actions contrary to group goals. 2) Output control, where the outcome is the basis of reward. 3) input control system which focuses on training and improvement of competence of employees. [12]. Out of these three systems, organizations can use any type of control system or a combination of different models. Selection of the control depends on the structure, norms, policies and administrative information in an organization [13].

There are multiple applications of Control Theory of Performance Management System at the workplace. To increase the performance of employees, managers must assign specific and challenging goals to employees that will upgrade their performance. However, organizations should avoid the ambiguous targets which do not have the specific standards and direct feedback [14]. Clear feedback and proper standards, provides employees the chance to correct errors. 
On the other hand, regular supervision in the workplace can be analyzed with the control system [15]. Similarly, managers can use the Control Theory in management program "facilitates tracking of performance and achievement by the continuous flow of feedback. [16].

\subsection{Research Paradigm}

Inspired by the Systems model of performance measurement as reflection of organizational effectiveness and efficiency [17], the research paradigm is designed. Figure 2 shows the research paradigm of the study. The Box 1 contains the inputs used in the study such as Guidelines on the Establishment and Implementation of the RPMS in the DepED, and the Guidelines in the Establishment and Implementation of Agency SPMS. The inputs were processed by the implementation of the RPMS. Thus, would measure the output of this study, the level of implementation of the RPMS. The research output "shall again form part of the feedback loop"; it may be perceived as the trial and testing policy on the implementation of the RPMS. Also, to create a suitable standard performance/effectiveness measurement of the subject matter. The cycle of input-process-out continues.

Input

Process

\section{Output}

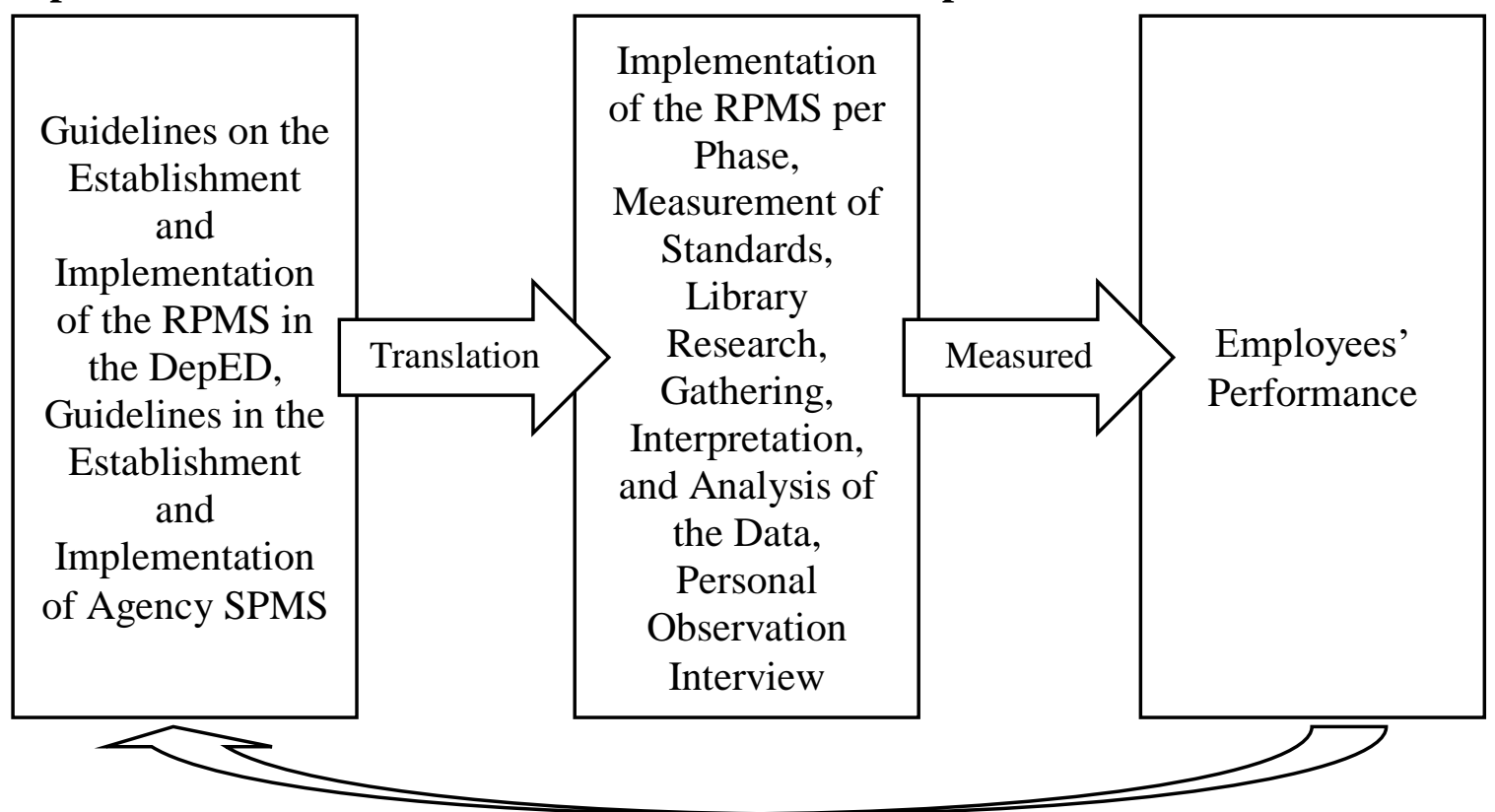

Figure 2: Research Paradigm

\section{Results and Discussions}

Presented on the succeeding pages are the data gathered and their interpretation based on the theory, model, objectives and policies cited earlier.

\subsection{Performance Planning and Commitment}

Presented below is the weighted mean of the responses of the respondents regarding the level of implementation of the RMPS in the performance planning and commitment phase. 


\begin{tabular}{|l|l|l|l|}
\hline No. & Variables & $\begin{array}{l}\text { Weighted } \\
\text { Mean }\end{array}$ & $\begin{array}{l}\text { Verbal } \\
\text { Interpretation }\end{array}$ \\
\hline 1 & $\begin{array}{l}\text { The rater explains thoroughly the importance of the } \\
\text { Results-Based Performance Management System. }\end{array}$ & 4.15 & To a Great Extent \\
\hline 2 & $\begin{array}{l}\text { The rater discusses methodically the different steps in } \\
\text { accomplishing the Individual Performance Review and } \\
\text { Commitment Form. }\end{array}$ & 3.39 & To a Little Extent \\
\hline 3 & $\begin{array}{l}\text { The rater assists the ratee in the formulation of } \\
\text { performance objectives. }\end{array}$ & 4.10 & To a Great Extent \\
\hline 4 & $\begin{array}{l}\text { The rater and the ratee both agree on the performance } \\
\text { targets written in the Individual Performance Review } \\
\text { and Commitment Form. }\end{array}$ & 4.20 & $\begin{array}{l}\text { To a Very Great } \\
\text { Extent }\end{array}$ \\
\hline 5 & $\begin{array}{l}\text { The rater checks analytically the performance indicators } \\
\text { written in each key result area. }\end{array}$ & 4.20 & $\begin{array}{l}\text { To a Very Great } \\
\text { Extent }\end{array}$ \\
\hline 6 & $\begin{array}{l}\text { The rater sees to it that the performance objectives are } \\
\text { aligned with the duties and responsibilities of the ratee. }\end{array}$ & 4.30 & $\begin{array}{l}\text { To a Very Great } \\
\text { Extent }\end{array}$ \\
\hline 7 & $\begin{array}{l}\text { The rater ensures that the performance targets can be } \\
\text { measured by the performance indicators set. }\end{array}$ & 4.24 & $\begin{array}{l}\text { To a Very Great } \\
\text { Extent }\end{array}$ \\
\hline 8 & $\begin{array}{l}\text { The rater checks whether the performance objectives } \\
\text { can be attained within the rating period. }\end{array}$ & 4.15 & To a Great Extent \\
\hline 9 & $\begin{array}{l}\text { The rater ensures that the performance objectives are } \\
\text { given reasonable corresponding weights (percentage). }\end{array}$ & 3.98 & To a Great Extent \\
\hline 10 & $\begin{array}{l}\text { The rater ensures that the Individual Performance } \\
\text { Commitment and Review Form is accomplished before } \\
\text { the start of the rating period. }\end{array}$ & 4.15 & To a Great Extent \\
\hline & $\begin{array}{l}\text { Grand Mean } \\
\text { To a Great } \\
\text { Extent }\end{array}$ \\
\hline
\end{tabular}

The data on the table shows that the item "the rater sees to it that the performance objectives are aligned with the duties and responsibilities of the ratee" obtained the highest weighted mean of 4.30 verbally interpreted as "to a very great extent". This means that the raters check carefully the contents of the Individual Performance Commitment and Review Form (IPCRF) of the ratee. They ensure that the variables written on the IPCRF arein congruence with the assigned duties and responsibilities of the ratee. The raters define the Key Result Areas (KRAs) as anchored on the organizational outcomes. The rater and the rate discuss and agree on the breakdown of the office KRAs into individual KRAs. KRAs are broad categories of general outputs or outcomes. These are the mandates or functions of individual employees. These are areas where the individual employees are expected to focus on [3].

On the other hand, the item "the rater discusses methodically the different steps in accomplishing the Individual Performance Review, and Commitment Form" got the lowest weighted mean of 3.39 inferred as "to a little extent". According to many respondents, the raters do not discuss with the raters how the IPCRF is being prepared. They are just tasked to prepare their own IPCRF, and then, later on, the raters will just check the contents of the form. The raters are just given manuals on how to fill out the form. The IPCRF is the form that reflects the individual commitments and performance of the individual employees [3]. 


\subsection{Performance Monitoring and Coaching}

Presented below are the weighted mean of the responses of the respondents regarding the level of implementation of the RMPS in the performance monitoring and coaching phase.

\begin{tabular}{|c|c|c|c|}
\hline No. & Variables & $\begin{array}{l}\text { Weighted } \\
\text { Mean }\end{array}$ & $\begin{array}{l}\text { Verbal } \\
\text { Interpretation }\end{array}$ \\
\hline 1 & $\begin{array}{l}\text { The rater provides key inputs about the ratee's } \\
\text { performance during the performance monitoring. }\end{array}$ & 3.20 & To a Little Extent \\
\hline 2 & $\begin{array}{l}\text { The rater directs the ratee's performance on certain } \\
\text { frequencies; not just once. }\end{array}$ & 3.39 & To a Little Extent \\
\hline 3 & $\begin{array}{l}\text { The rater clearly defines opportunities for } \\
\text { improvement of the ratee. }\end{array}$ & 3.60 & To a Great Extent \\
\hline 4 & $\begin{array}{l}\text { The raterasks from the ratee the evidences supporting } \\
\text { the latter's performance. }\end{array}$ & 4.25 & $\begin{array}{l}\text { To a Very Great } \\
\text { Extent }\end{array}$ \\
\hline 5 & $\begin{array}{l}\text { The rater practices the STAR (Situation, Task, Action, } \\
\text { and Results) Approach. }\end{array}$ & 4.15 & To a Great Extent \\
\hline 6 & $\begin{array}{l}\text { The rater asks the rate to trackthe latter's performance } \\
\text { against the targets. }\end{array}$ & 4.24 & $\begin{array}{lll}\text { To a Very Great } \\
\text { Extent }\end{array}$ \\
\hline 7 & $\begin{array}{l}\text { The rater provides coaching to the ratee to improve } \\
\text { work performance and behavior. }\end{array}$ & 4.19 & To a Great Extent \\
\hline 8 & $\begin{array}{l}\text { The rater records the critical incidences of the ratee on } \\
\text { the Performance Monitoring and Coaching Form. }\end{array}$ & 2.75 & To a Little Extent \\
\hline 9 & $\begin{array}{l}\text { The rater explains the impact of the critical incidences } \\
\text { on the job/action plan of the ratee. }\end{array}$ & 3.15 & To a Little Extent \\
\hline \multirow[t]{2}{*}{10} & $\begin{array}{l}\text { The rater ensures that there is two-way discussion } \\
\text { between him and the ratee. }\end{array}$ & 4.20 & $\begin{array}{l}\text { To a Very Great } \\
\text { Extent }\end{array}$ \\
\hline & Grade Mean & 3.71 & To a Great Extent \\
\hline
\end{tabular}

The table above indicates that the item "the raterasks from the ratee the evidences supporting the latter's performance" got the highest weighted mean of 4.25 verbally interpreted as "to a very great extent". The ratees said that during performance monitoring and coaching, the raters always check the former's evidence or means of verification. The raters make sure that all the accomplishments declared by the ratees are supported with appropriate documents.

Meanwhile, the item "the rater explains the impact of the critical incidences on the job/action plan of the ratee" obtained the lowest weighted mean of 3.15 interpreted as "to a little extent". According to the raters, the raters rarely discuss to them the critical incidents that occurred during the performance of the ratees' duties and responsibilities. Critical incidents are significant actual events and behaviors in which both positive and negative performance are observed and documented. Supposed to be, the critical incidents should be recorded in the Performance Monitoring and Coaching Form [3]. 


\subsection{Performance Review and Evaluation}

Presented on the next page is the weighted mean of the responses of the respondents regarding the level of implementation of the RMPS in the performance review and evaluation phase.

\begin{tabular}{|l|l|l|l|}
\hline No. & Variables & $\begin{array}{l}\text { Weighted } \\
\text { Mean }\end{array}$ & $\begin{array}{l}\text { Verbal } \\
\text { Interpretation }\end{array}$ \\
\hline 1 & The rater manages the meeting with the ratee. & 3.28 & Lo a Little Extent \\
\hline 2 & $\begin{array}{l}\text { The rater creates the right atmosphere during the } \\
\text { meeting. }\end{array}$ & 3.99 & To a Great Extent \\
\hline 3 & $\begin{array}{l}\text { The rater focuses on the performance issue, not on } \\
\text { the person. }\end{array}$ & 3.39 & Lo a Little Extent \\
\hline 4 & $\begin{array}{l}\text { The rater encourages the ratee to do self-appraisal. } \\
\text { The rater is fair and objective in evaluating the } \\
\text { performance of the ratee. }\end{array}$ & 2.15 & To a Great Extent \\
\hline 6 & $\begin{array}{l}\text { The rater ensures that the evaluation is based on } \\
\text { evidences. }\end{array}$ & 4.10 & Lo a Little Extent \\
\hline 7 & $\begin{array}{l}\text { The rater focuses on solving problems or correcting } \\
\text { a behavior. }\end{array}$ & 3.65 & To a Great Extent \\
\hline 8 & $\begin{array}{l}\text { The rater and the ratee adopt a joint problem } \\
\text { solving approach. }\end{array}$ & 3.40 & To a Great Extent \\
\hline 9 & $\begin{array}{l}\text { The rater evaluates the manifestations of each of } \\
\text { the ratee's competency. }\end{array}$ & 4.00 & To a Great Extent \\
\hline 10 & $\begin{array}{l}\text { The rater discusses strengths and improvement } \\
\text { needs. }\end{array}$ & 4.35 & $\begin{array}{l}\text { To a Very Great } \\
\text { Extent }\end{array}$ \\
\hline & Grand Mean & $\mathbf{3 . 7 2}$ & To a Great Extent \\
\hline
\end{tabular}

As shown in the table above, the item "the rater discusses strengths and improvement needs" got the highest weighted mean of 4.35 labeled as "to a very great extent". The raters normally identify the strong points of the ratees as well as their areas for improvement. The raters discuss carefully with the ratees their evaluation with regards to occupational competence and professional and personal characteristics.

On the other hand, the item "the rater is fair and objective in evaluating the performance of the ratee" obtained the lowest weighted mean of 2.84 interpreted as "to a little extent". There are many respondents who feel that their raters are biased when it comes to appraising their performances. Some respondents told that there are times that the raters are being subjective.

\subsection{Performance Rewards and Development Planning}

Presented below are the weighted mean of the responses of the respondents regarding the level of implementation of the RMPS in the performance rewards and development planning phase.

\begin{tabular}{|l|l|l|l|}
\hline No. & Variables & $\begin{array}{l}\text { Weighted } \\
\text { Mean }\end{array}$ & $\begin{array}{l}\text { Verbal } \\
\text { Interpretation }\end{array}$ \\
\hline 1 & The rater and the ratee identify development needs. & 4.24 & To a Very Great \\
\hline
\end{tabular}




\begin{tabular}{|l|l|l|l|}
\hline 2 & $\begin{array}{l}\text { The rater asks the rate to prepare action plans in order } \\
\text { to meet the development needs. }\end{array}$ & 3.28 & Extent \\
\hline 3 & $\begin{array}{l}\text { The rater links the ratee's performance rating to the } \\
\text { Performance-Based Incentive System specifically to } \\
\text { the Performance-Based Bonus and Step Increment. }\end{array}$ & 3.60 & To a Great Extent \\
\hline 4 & $\begin{array}{l}\text { The rater sends the ratee to seminars and workshops for } \\
\text { professional development. }\end{array}$ & 4.30 & $\begin{array}{l}\text { To a Very Great } \\
\text { Extent }\end{array}$ \\
\hline 5 & $\begin{array}{l}\text { The rater discusses and provides qualitative comments, } \\
\text { observations and recommendations to the ratee. }\end{array}$ & 4.33 & $\begin{array}{l}\text { To a Very Great } \\
\text { Extent }\end{array}$ \\
\hline 6 & $\begin{array}{l}\text { The rater considers the rates with high performance as } \\
\text { a candidate for promotion. }\end{array}$ & 4.10 & To a Great Extent \\
\hline 7 & $\begin{array}{l}\text { The rater assigns the ratee with high performance } \\
\text { rating to task forces, committees or special projects. }\end{array}$ & 3.78 & To a Great Extent \\
\hline 8 & $\begin{array}{l}\text { The rater introduces enhancements to the job of the } \\
\text { ratee. }\end{array}$ & 3.39 & To a Little Extent \\
\hline 9 & $\begin{array}{l}\text { The rater employs appropriate developmental } \\
\text { intervention. }\end{array}$ & 2.66 & To a Little Extent \\
\hline 10 & $\begin{array}{l}\text { The rater commends the high-performance rating of the } \\
\text { ratee. } \\
\text { Grand Mean }\end{array}$ & 4.20 & $\begin{array}{l}\text { To a Very Great } \\
\text { Extent }\end{array}$ \\
\hline & $\mathbf{3 . 7 9}$ & To a Great Extent \\
\hline
\end{tabular}

As reflected in the table, the item "the rater discusses and provides qualitative comments, observations and recommendations to the ratee" obtained the highest weighted mean of 4.33 tagged as "to a very great extent". The raters discuss with the ratees the competencies observed during the performance cycle. They identify the competencies which the ratees demonstrated consistently and the areas where the ratees failed to meet the expectations.

On the other hand, the item "the rater employs appropriate developmental intervention" got the lowest weighted mean of 2.66 verbally interpreted as "to a little extent". According to the respondents, their raters lack the essential knowledge in providing developmental interventions especially to low-performing employees where in fact, the raters should initiate the action plans and interventions for employee development. Ideally, the following should be used as developmental interventions: self-managed learning, benchmarking, functional cross-posting, coaching or counseling and many others [3].

\subsection{Overall Level of Implementation of the Results-Based Performance Management System}

Presented below is the summary of the levels of implementation of the Results-Based Performance Management System in the four phases.

\begin{tabular}{|l|l|l|}
\hline Phase & Weighted Mean & Verbal Interpretation \\
\hline Performance Planning and Commitment & 4.09 & To a Great Extent \\
\hline Performance Monitoring and Coaching & 3.71 & To a Great Extent \\
\hline Performance Review and Evaluation & 3.72 & To a Great Extent \\
\hline
\end{tabular}




\begin{tabular}{|l|l|l|}
\hline Performance Rewards and Development Planning & 3.79 & To a Great Extent \\
\hline Total & $\mathbf{3 . 8 3}$ & To a Great Extent \\
\hline
\end{tabular}

As displayed on the table above, the Results-Based Performance Management System is being implemented in the Department of Education Division of Gapan City to a great extent. However, the findings also revealed that there are areas in the RPMS which are not fully implemented.

\subsection{Challenges on the Implementation of the RPMS}

\begin{tabular}{|c|c|c|c|}
\hline No. & Variables & $\begin{array}{l}\text { Weighted } \\
\text { Mean }\end{array}$ & $\begin{array}{l}\text { Verbal } \\
\text { Interpretation } \\
\end{array}$ \\
\hline 1 & $\begin{array}{l}\text { Infrequent feedback - no formal feedback is given to the } \\
\text { ratee periodically. }\end{array}$ & 4.55 & Highly Evident \\
\hline 2 & $\begin{array}{l}\text { Lack of accountability - raters are not measured or held } \\
\text { accountable for providing accurate feedback. }\end{array}$ & 4.20 & Highly Evident \\
\hline 3 & $\begin{array}{l}\text { No comprehensive team assessment - although ratees on } \\
\text { the school are assessed, there is no simultaneous overall } \\
\text { assessment of the team. }\end{array}$ & 1.95 & Slightly Evident \\
\hline 4 & $\begin{array}{l}\text { Disconnected from rewards - getting a merit raise, bonus, } \\
\text { or promotion is completely disconnected from an } \\
\text { employee's performance appraisal scores. }\end{array}$ & 3.39 & $\begin{array}{l}\text { Moderately } \\
\text { Evident }\end{array}$ \\
\hline 5 & $\begin{array}{l}\text { No integration - the process is not fully integrated with } \\
\text { compensation, development, or staffing (internal } \\
\text { movement). }\end{array}$ & 2.65 & $\begin{array}{l}\text { Moderately } \\
\text { Evident }\end{array}$ \\
\hline 6 & $\begin{array}{l}\text { A focus on the squeaky wheel - the system focuses on } \\
\text { weak performers. }\end{array}$ & 3.35 & $\begin{array}{l}\text { Moderately } \\
\text { Evident }\end{array}$ \\
\hline 7 & $\begin{array}{l}\text { No second review - even though the process may have } \\
\text { impacts on salary, job security, and promotion, the } \\
\text { assessment is done by a single rater only. }\end{array}$ & 4.90 & Highly Evident \\
\hline 8 & $\begin{array}{l}\text { Cross-comparisons are not required - the system does } \\
\text { not require raters to do a side-by-side comparison, } \\
\text { comparing each ratee with one another. }\end{array}$ & 4.44 & Highly Evident \\
\hline 9 & $\begin{array}{l}\text { Assessments are kept secret - although a ratee's } \\
\text { performance rating may be posted on a wall, performance } \\
\text { appraisals are often kept secret. An overemphasis on } \\
\text { privacy concerns might allow raters to play favorites, to } \\
\text { discriminate, and to be extremely subjective. Keeping } \\
\text { ratings secret allows raters to avoid open conversations } \\
\text { about equity. }\end{array}$ & 4.45 & Highly Evident \\
\hline 10 & $\begin{array}{l}\text { The process is managed by raters who have no complete } \\
\text { understanding of performance and productivity. }\end{array}$ & 3.39 & $\begin{array}{l}\text { Moderately } \\
\text { Evident }\end{array}$ \\
\hline 11 & $\begin{array}{l}\text { Managers are not trained - raters are not trained on how } \\
\text { to assess and give honest feedback. }\end{array}$ & 3.35 & $\begin{array}{l}\text { Moderately } \\
\text { Evident }\end{array}$ \\
\hline 12 & $\begin{array}{l}\text { Recency errors - raters, especially those who don't } \\
\text { consult employee files and data, have a tendency to } \\
\text { evaluate based primarily on events that occurred during the }\end{array}$ & 4.46 & Highly Evident \\
\hline
\end{tabular}




\begin{tabular}{|c|c|c|c|}
\hline & last few months (rather than over the entire year). & & \\
\hline 13 & $\begin{array}{l}\text { Inconsistency across raters - some raters are naturally } \\
\text { "easy raters" while others are not. As a result, employees } \\
\text { working under easy managers have a better chance of } \\
\text { promotion due to their higher scores. Without } \\
\text { "benchmark" numbers to set as a standard, inconsistency } \\
\text { may be possible. }\end{array}$ & 4.48 & Highly Evident \\
\hline 14 & $\begin{array}{l}\text { High anxiety - uncertainty can cause many employees } \\
\text { high levels of anxiety weeks before the evaluation process. }\end{array}$ & 4.77 & Highly Evident \\
\hline 15 & $\begin{array}{l}\text { One-way communication - some raters simply give the } \\
\text { employee the form to quickly sign, and they don't even } \\
\text { solicit feedback. Ratees are intimidated by raters and the } \\
\text { process, and as a result, they say nothing during or after } \\
\text { the appraisal. }\end{array}$ & 3.35 & $\begin{array}{l}\text { Moderately } \\
\text { Evident }\end{array}$ \\
\hline 16 & $\begin{array}{l}\text { No alerts - the ratees are not notified midstream should } \\
\text { their performance change to the point where it was } \\
\text { suddenly dramatically below standards. }\end{array}$ & 4.13 & Evident \\
\hline 17 & $\begin{array}{l}\text { No appeal process }- \text { a ratee who disagrees with his } \\
\text { appraisal is seldom given the opportunity to challenge the } \\
\text { results with a neutral party. }\end{array}$ & 4.22 & Highly Evident \\
\hline 18 & $\begin{array}{l}\text { Many possible emotional consequences - if performance } \\
\text { appraisal is blotched, there is a possibility of the decrease } \\
\text { in ratee engagement, trust, rater brand strength, teamwork, } \\
\text { and innovation contribution. }\end{array}$ & 4.09 & Evident \\
\hline 19 & $\begin{array}{l}\text { A time-consuming process - most of the forms are } \\
\text { incredibly long and time-consuming. As a result, some } \\
\text { raters routinely recycle "last year's" evaluations. }\end{array}$ & 4.10 & Evident \\
\hline 20 & $\begin{array}{l}\text { It is historical - the process is focused on capturing } \\
\text { feedback about last year rather than on discussing } \\
\text { necessary changes to job and skill requirements. }\end{array}$ & 4.00 & Evident \\
\hline
\end{tabular}

The table above shows that the following are the top five challenges in the implementation of the Results-Based Performance Management System: "no second review," "high anxiety," "infrequent feedback," "inconsistency across raters," and "recency errors."

The item "no second review" obtained a weighted mean of 4.90 verbally interpreted as "highly evident." The results can be attributed to the fact that the assessment is done by a single rater only. No counter-checking or counter-evaluation is done to check the accomplishments of the ratees vis-à-vis the measures.

The item "high anxiety" got a weighted mean of 4.77 described as "highly evident". Given the many paper works including the preparation of evidences and documents to support their accomplishments, a majority of the respondents feel nervous weeks before the evaluation process. Many of them tend to be so busy during the preparation for the performance review and evaluation cycle. 
The item "infrequent feedback "is also a top challenge in the implementation of the RPMS with a 4.55 weighted mean which is also equivalent to "highly evident". Many respondents complained about the irregular feedbacks coming from their raters. According to them, feedbacks are important especially during the performance of their duties and responsibilities for them to know if they are doing well and to identify their strengths as well as their developmental needs.

The next serious challenge is the item "inconsistency across raters" which obtained a 4.48 weighted mean verbally interpreted as "highly evident". Majority of the respondents notice that some raters are naturally "easy raters" while others are not. As a result, ratees working under easy managers have a better chance of promotion due to their higher scores. Without "benchmark" numbers to set as a standard, inconsistency may be possible.

Lastly, the item "recency errors "got a 4.46 weighted mean which is verbally described as "highly evident". It has been found out that there are raters who have a tendency to evaluate the employee's performance based primarily on events that occurred during the last few months rather than over the entire year. Or simply, the majority of the raters only focus on the most recent memory rather than checking the performance of the ratees for the whole performance rating period. For example, a ratee was unable to satisfy or meet the expectations of the rater during the last few months of the performance rating period; there is a possibility that his performance rating will be low even though he has a good performance during the earlier months of the performance rating period.

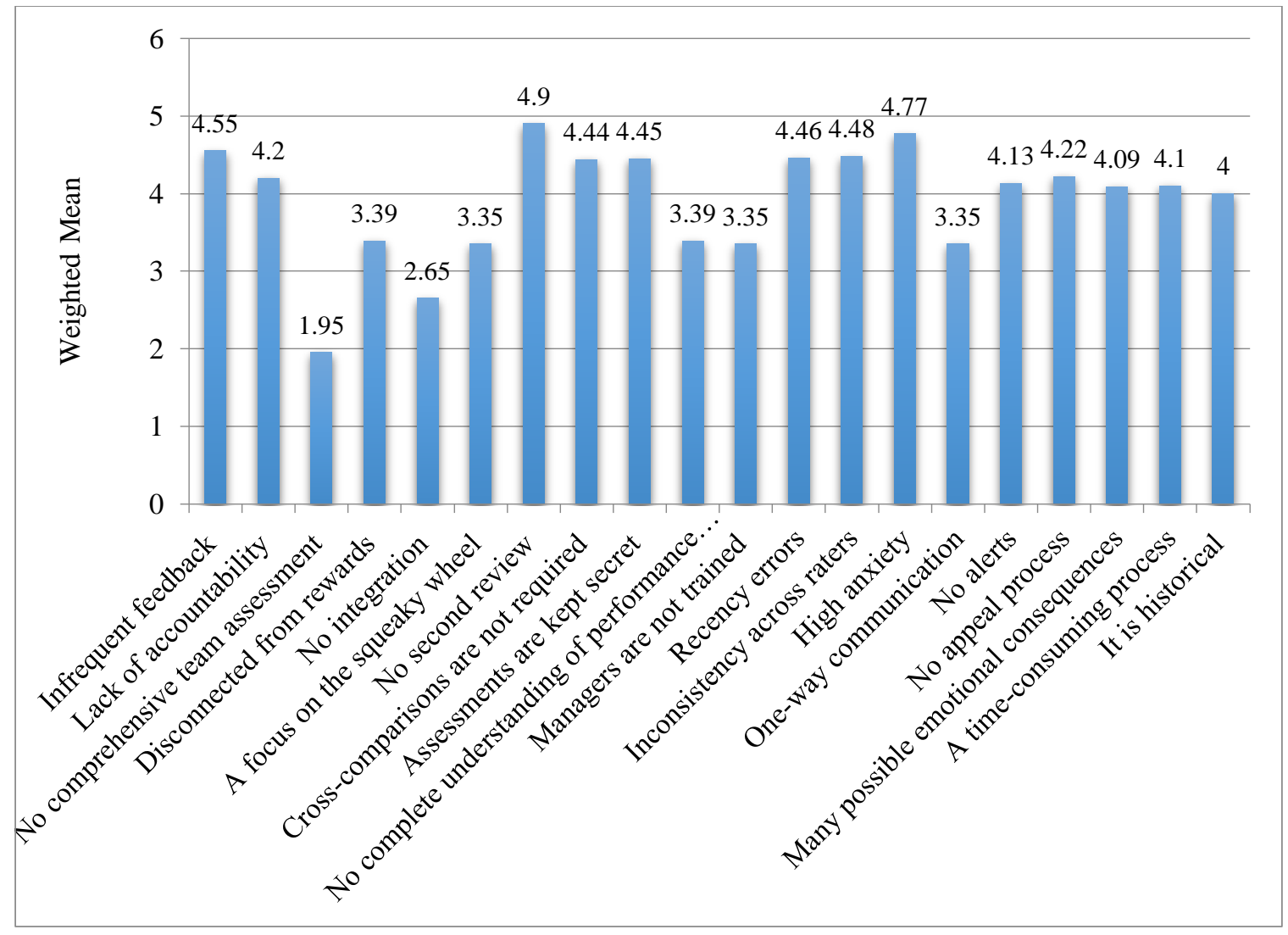

Figure 3: Challenges in the Implementation of the RPMS 


\section{Conclusions and Recommendations}

\subsection{Conclusion}

The purpose of this study was to measure the level of implementation of the Results-Based Performance Management System (RPMS) as a performance management tool in the Department of Education. It evaluated the level of implementation of the RPMS in terms of the four performance management phases namely: a) performance planning and commitment, b) performance monitoring and coaching, c) performance review and evaluation, and d) performance rewards and development planning, and the challenges in the implementation of the RPMS. Based on the findings, the following conclusions can be drawn from this study:

1) The Results-Based Performance Management System provides policies, specific mechanisms, criteria and processes for the performance target setting, monitoring, evaluation and development planning for the ratees. However, majority of the raters fail to discuss those with the ratees as well as how the Individual Performance Commitment and Review Form is being prepared.

2) The RPMS focuses on measures of performance vis-á-vis the targeted milestones, and provides a credible and verifiable basis for assessing the organizational outcomes and the collective performance of the government employees. While it is very important to ensure that organization effectiveness and individual improvement and efficiency are ensured, it is found out that there are raters who rarely provide feedback to the ratees.

3) The RPMS is effective when it comes to identifying the ratees' competencies as they are monitored to effectively plan the interventions needed for behavioral and professional development. However, the raters just lack the sufficient knowledge on what proper developmental intervention to employ for the ratees.

4) The RPMS makes use of performance indicators which are the exact quantification of objectives expressed through rubrics. The RPMS is an effective tool which gauges whether a performance is positive or negative. Unlike the previous performance evaluation forms which are Performance Appraisal System for Teachers and Performance Appraisal System for the Administrators and Staff, the RPMS shows effectiveness in assessing the employees' effectiveness, quality, efficiency and timeliness.

5) The performance management system promotes the performance evaluation based on evidences or means of verification. Every accomplishment or achievement declared by the ratees is counter-checked by the rater to ensure the veracity of the ratees' claims. Therefore, the performance management is based on a rational and factual basis for performance targets and measures.

6) The most serious challenges in the implementation of the RPMS are the following: "no second review," "high anxiety," "infrequent feedback," "inconsistency across raters," and "recency errors."

\subsection{Recommendations}

Based on the existing policies and the findings of this study, the researcher arrived to the following recommendations:

1) The raters should discuss methodically with the ratees how the RPMS works and how the Individual Performance Commitment and Review Form is being prepared. The key 
results areas, objectives and performance indicators, as anchored on the overall organizational effectiveness, should be discoursed effectively with the ratees.

2) The raters should provide the necessary feedback to the ratees as often as possible to determine the progress of the ratees in achieving their objectives. A mid-year or quarterly review can be prescribed in order for the raters to provide coaching, feedbacks and appropriate interventions for the ratees.

3) The raters should be properly trained in planning and providing the necessary interventions for the ratees. As provided in the DepEd Order No. 2, s. 2015, the following developmental action plans can be used for the ratees: self-managed learning, benchmarking, functional cross-posting, coaching / counseling, and many others [3].

4) The grants of performance-based incentives shall be based on the final ratings of the employees. At present, the employees' incentives, specifically those of the teachers, are based on the achievement of the school and the students and not on their individual accomplishments.

5) Strengthen the roles of the Performance Management Teams (PMT) to ensure that the individual performance of the employees is properly assessed, without biased. The PMTs must validate the performance ratings of the ratees.

6) Follow the provisions of the RPMS Guidelines stating the establishment of a Grievance Committee to act as appeals board on all issues relating to the implementation of the RPMS.

\section{Appendices}

\section{Survey Questionnaire}

\subsection{Level of Implementation of the Results-Based Performance Management System}

\section{Instruction}

This portion will describe the level of implementation of the Results-based Performance Management System in the following phases: performance planning and commitment, performance monitoring and coaching, performance review and evaluation and performance rewards and development planning. Put a check inside the column of each item which corresponds to your answer. Please answer each item honestly by using the following scale in answering each item:

$\begin{array}{lll}5 & = & \text { To a Very Great Extent } \\ 4 & = & \text { To a Great Extent } \\ 3 & = & \text { To a Little Extent } \\ 2 & = & \text { To a Very Little Extent } \\ 1 & = & \text { No Extent At All }\end{array}$

Performance Planning and Commitment

\begin{tabular}{|l|c|c|c|c|c|c|}
\hline No. & \multicolumn{1}{|c|}{ Considerations } & $\mathbf{5}$ & $\mathbf{4}$ & $\mathbf{3}$ & $\mathbf{2}$ & $\mathbf{1}$ \\
\hline $\mathbf{1}$ & $\begin{array}{l}\text { The rater explains thoroughly the importance of the Results- } \\
\text { Based Performance Management System. }\end{array}$ & & & & \\
\hline $\mathbf{2}$ & The rater discusses methodically the different steps in & & & & \\
\hline
\end{tabular}




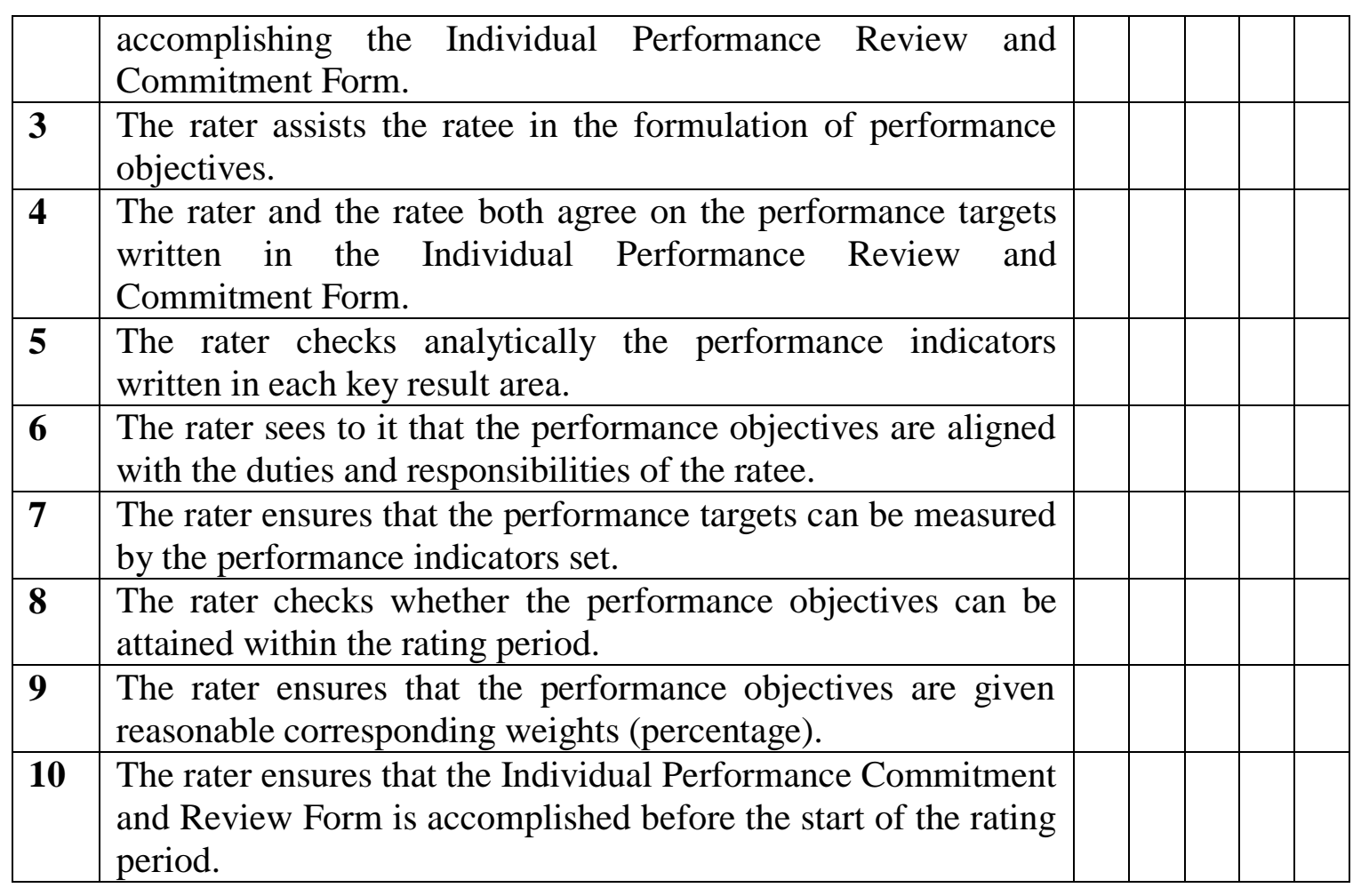

Performance Monitoring and Coaching

\begin{tabular}{|c|c|c|c|c|c|c|}
\hline No. & Considerations & 5 & 4 & 3 & 2 & 1 \\
\hline 1 & $\begin{array}{l}\text { The rater provides key inputs about the ratee's performance } \\
\text { during the performance monitoring. }\end{array}$ & & & & & \\
\hline 2 & $\begin{array}{l}\text { The rater directs the ratee's performance on certain frequencies; } \\
\text { not just once. }\end{array}$ & & & & & \\
\hline 3 & $\begin{array}{l}\text { The rater clearly defines opportunities for improvement of the } \\
\text { ratee. }\end{array}$ & & & & & \\
\hline 4 & $\begin{array}{l}\text { The raterasks from the ratee the evidence supporting the latter's } \\
\text { performance. }\end{array}$ & & & & & \\
\hline 5 & $\begin{array}{l}\text { The rater practices the STAR (Situation, Task, Action and } \\
\text { Results) Approach. }\end{array}$ & & & & & \\
\hline 6 & $\begin{array}{l}\text { The rater asks the rate to trackthe latter's performance against } \\
\text { the targets. }\end{array}$ & & & & & \\
\hline 7 & $\begin{array}{l}\text { The rater provides coaching to the ratee to improve work } \\
\text { performance and behavior. }\end{array}$ & & & & & \\
\hline 8 & $\begin{array}{l}\text { The rater records the critical incidences of the ratee on the } \\
\text { Performance Monitoring and Coaching Form. }\end{array}$ & & & & & \\
\hline 9 & $\begin{array}{l}\text { The rater explains the impact of the critical incidences on the } \\
\text { job / action plan of the ratee. }\end{array}$ & & & & & \\
\hline 10 & $\begin{array}{l}\text { The rater ensures that there is the two-way discussion between } \\
\text { him and the ratee. }\end{array}$ & & & & & \\
\hline
\end{tabular}


Performance Review and Evaluation

\begin{tabular}{|c|c|c|c|c|c|c|}
\hline No. & Considerations & 5 & 4 & 3 & 2 & 1 \\
\hline 1 & The rater manages meeting with the ratee. & & & & & \\
\hline 2 & The rater creates the right atmosphere during the meeting. & & & & & \\
\hline 3 & The rater focuses on the performance issue, not on the person. & & & & & \\
\hline 4 & The rater encourages the ratee to do self-appraisal. & & & & & \\
\hline 5 & $\begin{array}{l}\text { The rater is fair and objective in evaluating the performance of } \\
\text { the ratee. }\end{array}$ & & & & & \\
\hline 6 & The rater ensures that the evaluation is based on evidences. & & & & & \\
\hline 7 & The rater focuses on solving problems or correcting a behavior. & & & & & \\
\hline 8 & The rater and the ratee adopt a joint problem-solving approach. & & & & & \\
\hline 9 & $\begin{array}{l}\text { The rater evaluates the manifestations of each of the ratee's } \\
\text { competency. }\end{array}$ & & & & & \\
\hline 10 & The rater discusses strengths and improvement needs. & & & & & \\
\hline
\end{tabular}

Performance Rewards and Development Planning

\begin{tabular}{|c|c|c|c|c|c|c|}
\hline No. & Considerations & 5 & 4 & 3 & 2 & 1 \\
\hline 1 & The rater and the ratee identify development needs. & & & & & \\
\hline 2 & $\begin{array}{l}\text { The raterasks the rate to prepare action plans in order to meet } \\
\text { the development needs. }\end{array}$ & & & & & \\
\hline 3 & $\begin{array}{l}\text { The rater links theratee's performance rating to the } \\
\text { Performance-Based Incentive System specifically to the } \\
\text { Performance-Based Bonus and Step Increment. }\end{array}$ & & & & & \\
\hline 4 & $\begin{array}{l}\text { The rater sends the ratee to seminars and workshops for } \\
\text { professional development. }\end{array}$ & & & & & \\
\hline 5 & $\begin{array}{l}\text { The rater discusses and provides qualitative comments, } \\
\text { observations, and recommendations to the ratee. }\end{array}$ & & & & & \\
\hline 6 & $\begin{array}{l}\text { The raterconsiders the rates with high performance as a } \\
\text { candidate for promotion. }\end{array}$ & & & & & \\
\hline 7 & $\begin{array}{l}\text { The rater assigns the ratee with high performance rating to task } \\
\text { forces, committees or special projects. }\end{array}$ & & & & & \\
\hline 8 & The rater introduces enhancements to the job of the ratee. & & & & & \\
\hline 9 & The rater employs appropriate developmental intervention. & & & & & \\
\hline 10 & The rater commends the high-performance rating of the ratee. & & & & & \\
\hline
\end{tabular}

\subsection{Challenges in the Implementation of the Results-based Performance Management System}

\section{Instruction}

This portion will describe the challenges faced by the teachers and the raters in the implementation of the Results-based Performance Management System. Put a check inside the column of each item which corresponds to your answer. Please answer each item honestly by using the following scale in answering each item:

$5=$ Highly Evident

$4=$ Evident 
$3=$ Moderately Evident

$2=$ Slightly Evident

$1=$ Not Evident

\begin{tabular}{|c|c|c|c|c|c|}
\hline No. & Considerations & 5 & 4 & $\mathbf{3}$ & 2 \\
\hline 1 & $\begin{array}{l}\text { Infrequent feedback - no formal feedback is given to the } \\
\text { ratee periodically. }\end{array}$ & & & & \\
\hline 2 & $\begin{array}{l}\text { Lack of accountability - raters are not measured or held } \\
\text { accountable for providing accurate feedback. }\end{array}$ & & & & \\
\hline 3 & $\begin{array}{l}\text { No comprehensive team assessment - although ratees on the } \\
\text { school are assessed, there is no simultaneous overall } \\
\text { assessment of the team. }\end{array}$ & & & & \\
\hline 4 & $\begin{array}{l}\text { Disconnected from rewards - getting a merit raise, bonus, or } \\
\text { promotion is completely disconnected from an employee's } \\
\text { performance appraisal scores. }\end{array}$ & & & & \\
\hline 5 & $\begin{array}{l}\text { No integration - the process is not fully integrated with } \\
\text { compensation, development, or staffing (internal movement). }\end{array}$ & & & & \\
\hline 6 & $\begin{array}{l}\text { A focus on the squeaky wheel - the system focuses on weak } \\
\text { performers. }\end{array}$ & & & & \\
\hline 7 & $\begin{array}{l}\text { No second review - even though the process may have } \\
\text { impacts on salary, job security, and promotion, the } \\
\text { assessment is done by a single rater only. }\end{array}$ & & & & \\
\hline 8 & $\begin{array}{l}\text { Cross-comparisons are not required - the system does not } \\
\text { require raters to do a side-by-side comparison, comparing } \\
\text { each ratee with one another. }\end{array}$ & & & & \\
\hline 9 & $\begin{array}{l}\text { Assessments are kept secret - although a ratee's } \\
\text { performance rating may be posted on a wall, performance } \\
\text { appraisals are often kept secret. An overemphasis on privacy } \\
\text { concerns might allow raters to play favorites, to discriminate, } \\
\text { and to be extremely subjective. Keeping ratings secret allows } \\
\text { raters to avoid open conversations about equity. }\end{array}$ & & & & \\
\hline 10 & $\begin{array}{l}\text { The process is managed by raters who have no complete } \\
\text { understanding of performance and productivity. }\end{array}$ & & & & \\
\hline 11 & $\begin{array}{l}\text { Managers are not trained - raters are not trained on how to } \\
\text { assess and give honest feedback. }\end{array}$ & & & & \\
\hline 12 & $\begin{array}{l}\text { Recency errors - raters, especially those who don't consult } \\
\text { employee files and data, have a tendency to evaluate based } \\
\text { primarily on events that occurred during the last few months } \\
\text { (rather than over the entire year). }\end{array}$ & & & & \\
\hline 13 & $\begin{array}{l}\text { Inconsistency across raters - some raters are naturally "easy } \\
\text { raters" while others are not. As a result, employees working } \\
\text { under easy managers have a better chance of promotion due } \\
\text { to their higher scores. Without "benchmark" numbers to set } \\
\text { as a standard, inconsistency may be possible. }\end{array}$ & & & & \\
\hline 14 & $\begin{array}{l}\text { High anxiety - uncertainty can cause many employees high } \\
\text { levels of anxiety weeks before the evaluation process. }\end{array}$ & & & & \\
\hline
\end{tabular}




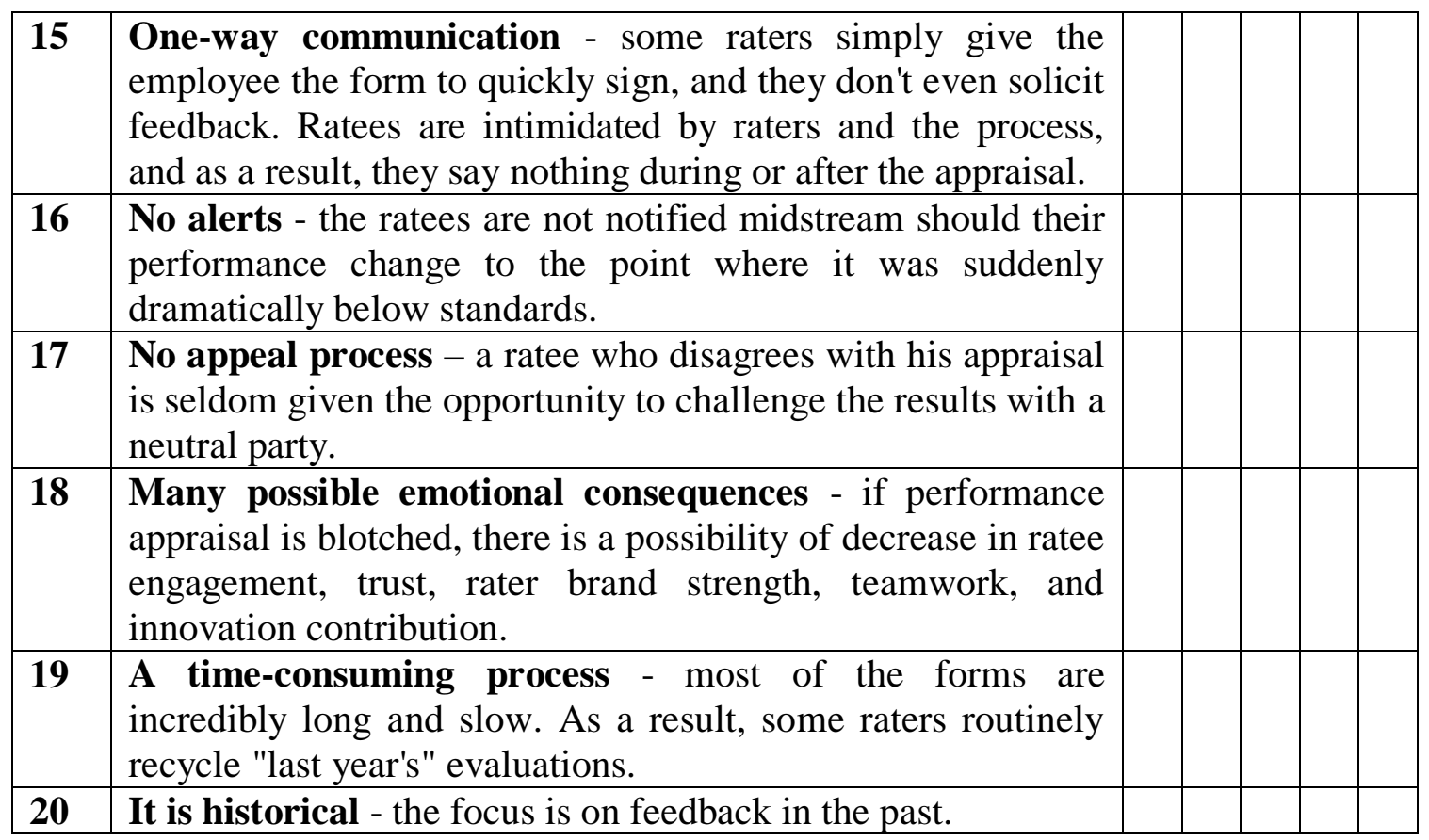

\section{References}

[1] Macky,K.,\& Johnson, G. (2000).The Strategic Management of Human Resources in New Zealand. Auckland, New Zealand: Irwin/McGraw-Hill

[2] Republic Act No. 9155. Governance of Basic Education Act of 2001.

[3] Department of Education. DepEd Order No. 2, s. 2015 (Guidelines on the Establishment and Implementation of the Results-Based Performance Management System (RPMS) in the Department of Education), 2015.

[4] Civil Service Commission, 2017.

[5] Civil Service Commission. CSC Memorandum Circular (MC) 06, s. 2012 (Guidelines for the Establishment and Implementation of Agency Strategic Performance Management System), 2012.

[6] Stevers, B.P. and Joyce,T. (2000), "Building a balanced performance management system" SAM Advanced Management Journal, Vol.8

[7] Ying Ying, Z. (2012). The Impact of Performance Management System on Employee performance. essay.utwente.nl/62260/1/Daisy-master_thesis.pdf

[8] Department of Education. www.deped.gov.ph. 2017.

[9] Department of Education Division of Gapan City Planning Unit. Report on Enrollment. 2017.

[10] Department of Education Division of Gapan City Human Resource Unit. Personnel Data Bulletin. 2017.

[11] Barrows, E., \& Neely, A. (2012). Managing Performance in Turbulent Times: Analytics and Insight - Ed Barrows, Andy Neely. New Jersery: John Wiley \& Son Inc.

[12] Krausert, A. (2009). Performance Management for Different Employee Groups: A Contribution to the Employment Systems Theory. Heidelberg: Springer- Verlag.

[13] Shell, S. A. (1992). Control Theory in Strategic Human Resource Management: The Mediating Effect of Administrative Information. Academy of Management Journal, 35(2), 292-327.

[14] Campion, M. A., \& Lord, G. R. (1982). A Control Systems Conceptualization of the Goal-Setting and Changing Process. Organizational Behavior and Human Performance, 30(2), 265-287.

[15] Carver, C. S., \& Scheier, M. F. (1981). Attention and Self-Regulation: A Control-Theory Approach to Human Behavior. New York: Springer-Verlag. 
[16] Pennsylvania State University World Campus, 2016.

[17] Gabriel A G and Manuela GP(2017) Praxis in Local Legislative Governance: Measure of Organizational Effectiveness of the Component Cities in Nueva Ecija, Philippines Asia Pacific Journal of Multidisciplinary Research Vol. 5 No.2, 12-20 May 2017 P-ISSN 2350-7756 E-ISSN 2350-8442 www.apjmr.com

*Corresponding author.

E-mail address: anthonybasasanpedro@yahoo.com 